\title{
Methodology of MANET Route Formulation and Tracking Nodes Energy Expenditure in Ubicomp MANETs Using NS2.
}

\author{
M. Kaleem GALAMALI, Assoc. Prof Nawaz MOHAMUDALLY
}

\begin{abstract}
In all engineering fields, as development proceeds, the notion of reliability start creeping in mostly with the aim of satisfying dependability and day-to-day running of the technology. Ubicomp is not spared from this need for reliability [1]. Quite some research has been done in this direction [14-65] whereby a total of sixteen new metrics have been studied with the aim of formulating reliability predictability features for MANETs in Ubicomp. In a prior paper [66], it was mentioned that the methodology used for developing results over the sixteen metrics, was also novel and involved implementing components not previously available. The methodology is split into five steps.
\end{abstract}

In this paper, the second step concerning methodology for "MANET Route Formulation" and "Tracking Nodes Energy Expenditure" together with its design and implementation particularities are put forward. It is pointed out that this work is carried out irrespective of concerns for MANET nodes being supplied as infrastructure or not.

The results of this study may serve towards better formulation of methodology for MANET Route Formulation and tracking of energy expenditure in other ubicomp topographies or using this methodology to prepare many off-the-shelf such components over different movement and communication patterns. These components would eventually be facilitators for further empirical research activities. This paper is a retrospective delivery of the second of five parts of the methodology developed over which previous work [14-65] was built over. It also follows the delivery of the first part of the methodology [66].

Key terms: Ubicomp- Ubiquitous Computing, CBR- Constant Bit Rate, MANET- Mobile Adhoc Network, NS2- Network Simulator 2.

M. Kaleem GALAMALI,

University of Technology Mauritius (student) Mauritius

Assoc. Prof Nawaz Mohamudally University of Technology Mauritius, Mauritius

\section{Introduction}

Future ubicomp designs are expected to incorporate increasing amounts of reliability components including adaptability requirements with respect to energy consumption and packet distance coverages. For this purpose, knowledge about applicable metrics and their theoretical trends will prove useful. Such work have been attempted previously [14-65]. It is also important to know the novel methodology developed, including its design concerns. As stated in previous paper [66], the methodology was split into five components.

i. Tracking of exact positions of ubicomp MANET nodes.

ii. MANET Route formulation and tracking nodes energy expenditure.

iii. Processing of MANET_Routes_Packets_Per_CBR

iv. MANET Results Generations.

v. Automated Extraction of Data From Files

The work published previously [14-65] were based on application of exact location-awareness at per packet transmission level. A previous work describing the methodology for tracking of Exact positions of ubicomp MANET nodes has been performed [66]. The second part of the methodology mentioned above and illustrated as a key contribution of this paper is built over the first part for exact position tracking of ubicomp MANET nodes. It is recalled that simulator software NS2 has been used with a topography of $300 \mathrm{x}$ $300 \mathrm{~m}^{2}$. The rest of this paper is organised as follows: section 2: Experimental set-up used, section 3: Methodology Details and Section 4: Conclusion and References.

\section{Experimental Set-Up Used.}

The same experimental set-up described in previous paper [66] is applied here again.

\section{Methodology Details.}

\subsection{Component Re-Use from Previous Work.}

Many Components devised previously have been reused here. These include the "Per_Packet_Cbr_track_index" files which are intermediate results files worked with in previous papers [3-5]. The other main component used has been the exact location track files illustrated in previous paper [66].

The component re-use approach is more appropriate due to the benefit of reduction in time spent for achieving results.

\subsection{Experiment Design.}


For each packet of each CBR, the corresponding record from file "Per_packet_cbr_track_index" is extracted (referred to as R1) as well as the corresponding time (referred to as t1) at which this packet has been transmitted. The corresponding file for node_positions detailed in previous paper [66], is opened and the record corresponding to time $\mathrm{t} 1$ is extracted (referred to as R2). Using R1 and exact node-positions in R2, a route must be computed.

The procedure for computing the route is simple. Start from the sender position (S1), evaluate which other yetunused (n1) node is closest to it. Then compute energy expenditure from sender to this next_node (n1). Then from this node $\mathrm{n} 1$, repeat the procedure for remaining unused nodes. Finally, the hop_count also is calculated. The process is repeated for record next to R1.

The record contains the exact positions of sender and targeted receiver at that time, the nodes in sequential order that the packet will follow, the square_distance between the intermediate pair of nodes and corresponding energy_consumed by intermediate nodes in sequence followed by hop_count.

The method can be considered a brute-force method and will take lots of time for execution and many issues were also to be considered in successive sub-sections.

\subsubsection{Need for same program to run for varying node}

\section{densities.}

The program must be designed in such a way that it can work for varying Constant Bit Rates (CBRs) and varying node densities. It is not already granted in NS2, explicit program design to cater for it must be incorporated. Hence, a variable opt(nn) is used and changed as and when needed, to execute same program for different node densities. It also allowed for executing successive simulation runs in loops.

\subsubsection{File and Folder Design.}

Since lots of data generation is expected, an easy to work format for file and folder design had to be formulated as shown in figure 1. Two folders were created:

$$
\begin{aligned}
\text { i. } & \text { CBR_tracks } \\
\text { ii. } & \text { Whole_sim_tracks }
\end{aligned}
$$

In the folder "CBR_tracks", a folder "MANET_routes_packets_per_CBR" is created. Also, the files for "per_packet_cbr_tracks" corresponding to each movement scenario is kept in folder CBR_tracks. These will be in folders as follows "movement0", "movement1", etc. Since they would occupy huge space (above $35 \mathrm{~GB}$ ), each folder is copied and deleted as needed.
Inside the folder "MANET_routes_packets_Per_CBR", a folder for each node-density is created starting from "node_num_7", "node_num_8", "node_num_9" .... until "node_num_56". Inside each of these folders, 60 folders are created as follows "movement_0", "movement_1", etc. Each folder will correspond to the folder for "per_packet_cbr_tracks" and will store MANET_Route files corresponding to "per_packet_cbr_track" files.

Inside the folder "whole_sim_tracks" will be ten folders corresponding the first ten entries of tabular information in section 3.10 of previous paper [66]. The folders will be named as follows: "node_num_9", "node_num_12", "node_num_16" etc. In each folder, will be 60 files corresponding to each movement file where the whole_simulation node position tracks will be stored.

This folder arrangement has been applied uniformly throughout this section of experiments. The folder names for folders "MANET_Routes_per_packet_cbr", "per_packet_CBR_track" and each of the ten folders in whole_sim_tracks will have their names followed by their index numbers. These index_numbers will be made use of in programs for execution to make same program run for different input conditions and output in appropriate files.

\subsubsection{Optimisation for searching in file.}

This kind of information processing is heavily dependent on appropriate program design which makes most economic execution in terms of execution time and to some extent requires amount of main memory present also.

In each of the ten folders under folder "whole_sim_tracks", one folder named "summary_every_2000_lines" is created. For each of the 60 "whole_movement_track_files", illustrated in previous paper [66], a summary file for time track corresponding to every $2000^{\text {th }}$ record is kept. This will facilitate searching into the "whole_movement_track" files as each of these are of between 94000 and 100 000 records. If a CBR start time corresponds to record number 65 000, then searching from 0 until 65000 will take really lots of time for comparisons. Instead, direct reading from summary file is made to have a better starting point in the file. Here, a starting point at line number 64000 will be obtained. In program execution, 64000 records is gone through in a while loop without searching and is hence much quicker. Hence, only 1000 extra searching is done before reaching the effective record to start from, reducing time wasted to very small amount. Worst case extra searching would be 1999 
Proc. of The Seventh Intl. Conf. On Advances In Computing, Control And Networking - ACCN 2017

Copyright (C) Institute of Research Engineers and Doctors, USA .All rights reserved.

ISBN: 978-1-63248-134-4 doi: 10.15224/ 978-1-63248-134-4-15

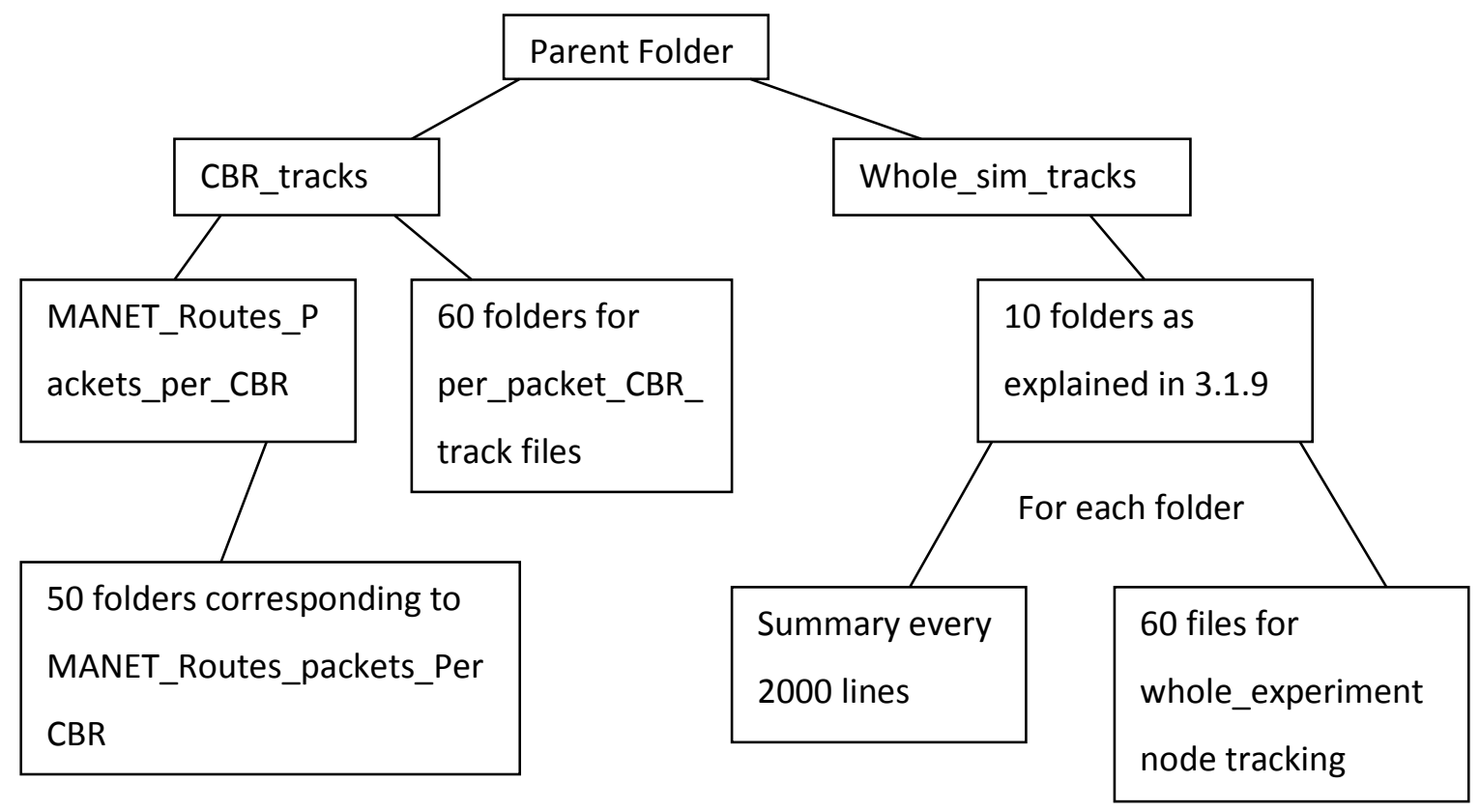

Figure 1: File and Folder Design for MANET Route Formulation and nodes energy expenditure

extra lines. Processing described in section 3.2 of this paper, is carried out before going to next CBR packet.

Progresses reached in both files "per_packet_cbr_track" and "whole_sim_track_movement" are kept alongside with the progress in record sequence of "MANET_Routes_Packets_per_CBR" files. For successive record of processing, progress forward in each file is performed. Overall, for each CBR, the files "whole_simulation_track_movement" and the "per_packet_CBR_track" is gone though only once. It would have been disastrous, in terms of processing time, to restart search in "whole_simulation_track_movement" files for each successive record in a "per_packet_cbr_track" files.

\subsubsection{Consideration for Storage Capacity.}

Records of data detailed in section 3.2 of this paper after the second paragraph, depict certain removable data like cbr(26), track_time, s_x, s_y, r_x, r_y, v_n, sq_d, e_c, hops, endl. These can be causing extra storage space needs as these will be repeated in every record. However, they are being maintained for reasons of ease of reading and debugging in case of wrongly stored record. "e_c", "sq_d" and "v_n" are short for "energy_consumed", "square_distance" and "via_nodes" and hence reduce consumption of storage space.

For small number of nodes (e.g. 7 or 8 ) total data for the 105 files for "MANET_routes_packets_per_CBR" in one folder, storage size needed is less than $1 \mathrm{~GB}$. This tends to increase for increasing number of nodes in the topography as more nodes are used to form a route, requiring more data in one record. For node number 56, individual folders of size $3.3 \mathrm{~GB}$ were noted.

Hence, several GB or even a few $\mathrm{TB}$ of info is expected. With external hard disks of 2 TB or even 3 TB available on the market, at the time this research is being undertaken, 3 such hard disks may be required. The data obtained on internal hard disks of the laptops after processing, may be transferred to the hard disks of the laptops after processing, may be transferred to the external storage once a folder for "MANET_routes_packet_per_CBR" is complete. The copy on hard-disk of laptops may then be deleted if no longer required, freeing space for other work.

\subsubsection{Experiment Execution.}

The experiments have been designed to run in loops for "node_numbers" for each movement number.

\begin{tabular}{|c|l|}
\hline Round & Node number \\
\hline 1 & $9,8,7$ (or $7,8,9$ in ascending order) \\
\hline 2 & $12,11,10$ \\
\hline 3 & $16,15,14,13$ \\
\hline 4 & $20,19,18,17$ \\
\hline 5 & $25,24,23,22,21$ \\
\hline 6 & $30,29,28,27,26$ \\
\hline 7 & $36,35,34,33,32,31$ \\
\hline 8 & $42,41,40,39,38,37$ \\
\hline 9 & $49,48,47,46,45,44,43$ \\
\hline 10 & $56,55,54,53,52,51,50$ \\
\hline
\end{tabular}

Table 1: Experiment Loop Execution Design 
The computation, in each laptop available, is carried out in rounds as in Table 1 for each movement.

The above rounds correspond to the table identified in section 3.2 of previous paper [66]. Each round is carried in one loop. Each round represent a maximum number of node of the form $\mathrm{n}^{2}$ or $\mathrm{n}(\mathrm{n}-1)$, representing an initial uniform placement of nodes remaining constant as value of node_number increases until next value of $n^{2}$ or $n(n-1)$ is crossed, e.g. initial node positions in node_num 7 until 9 are same but changes at 10 until 12, then change again for 13 until 16 , then change again for 17 until 20 , then change again for 21 until 25 etc...

It was noted that 2 simultaneous streams of execution could be run fairly at optimised hardware performance corresponding to a core i5 processor. Each stream is run for a range of cbr indices. Stream 1 is run for cbrs 0 until 49 executing in a loop, stream 2 is run for cbrs 0 until 49 executing in a loop, stream 2 is run for cbrs 50 until 104 in a loop. These 2 streams progress fairly at same speed. The 2 streams are left to execute continuously 24 hour round. The program code for each stream is stored in separate file each.

In case, an execution is projected to finish during the night (or before next inspection), another pair of streams of execution stored in yet another pair of files (totalling 4 files for loop execution of MANET routes) is activated for next movement and each is executed in a separate terminal. The execution times for each of the four parallel streams are increased but overall, the continuity of execution is much better achieved to optimally benefit from time. The need for interventions (especially during the night) to inspect and restart next loop execution is hence completely eliminated, which gives a better atmosphere for managing the research activity. Frequency of inspections really necessary were about 2 to 4 times daily; since all the laptops are not of same power, they do not have same progress amounts at same time. A few inspections did reveal certain errors in record storage mostly in files for "packet_per_cbr" and "whole_simulation_track", but these have mostly been easy to cater for and no further report of it is felt necessary.

\subsubsection{Execution times and Rate of Data Generation.}

The major factor for execution time is that the initial algorithm developed is a brute-force approach as stated under heading "Experiment Design" in section 3.2 of this paper. At worst case situation, the processing for number of nodes $n$ is carried out $n$ ! (factorial of $n$ ) times. Execution time tends to vary proportionally to this value of $n$ !. For node_num 7,8 and 9 , the execution times were fairly acceptable at 1 round for 2 movements within 24 hours. This was not being so far bigger node numbers like 11 and 12 where more than 30 hours were required even on the most powerful fujitsu core i5 laptop available. This was expected to increase drastically over successive number of nodes and would surely be catastrophically time consuming for node numbers 50 and above. This problem was noted early enough and decision to look for optimising the algorithm is taken early.

The rate of data generation for execution of loops for low number of nodes of 7,8 and 9 was around $300 \mathrm{~KB} / \mathrm{s}$ for each stream of execution totalling $600 \mathrm{~KB} / \mathrm{s}$ for 2 streams in one laptop. This was fair. For node number 11 , rate of data generation visually observable per stream was around $260 \mathrm{~KB} / \mathrm{s}$. this tendency is expected to continue for higher number of nodes where sizes of output files were expected to increase but their data generation rate would decrease dramatically. This further reinforced the need for optimisation.

\subsubsection{Optimisation Method for algorithm devised.}

It was observed that movement and communication patterns were same within node_numbers identified in each round with just one difference: decrementing from the biggest $n^{2}$ or $n(n-1)$ value, e.g. 12 to 11 , only node 12 would be absent and MANET Route computation has to be done only for first 11 nodes. Same for 11 to 10 nodes, only node 11 would be absent and MANET Route computation carried out for first 10 nodes only. This observation applies in each round starting from highest node_num value and decrementing until least node_num value in that round. Using this observation, following sequence is devised as optimisation attempt:

1. Start Execution from biggest node_number in a round.

2. For the biggest node_number value $\left(n^{2}\right.$ or $\left.n(n-1)\right)$ in a round, perform the raw brute-force algorithm for MANET Route formulation as described in section 3.2 in this paper for every record in the CBR_file.

3. Then go to next smaller node_number, $\mathrm{n}_{2}$ in the round.

4. For processing of the CBR, open the corresponding file MANET_routes_packets_per_CBR (f2) in the next bigger node_number $\left(\mathrm{n}^{2}+1\right)$.

5. For each packet of transmission in the CBR corresponding to records in files, examine the corresponding record in file $\mathrm{f} 2$. If it does not contain the last node number index $\left(n^{2}+1\right)$, go to step 6. If it does, go to step 7.

6. If the record does not contain node number $\left(\mathrm{n}^{2}+1\right)$ in the route formed for $\mathrm{f} 2$, then this route will be 
same for file MANET_routes_packets_per_CBR corresponding to $\mathrm{n}_{2}$.

7. If the record does contain node_number $\left(\mathrm{n}_{2}+1\right)$, then the MANET routes must be recomputed as in step 2 nut only for that particular record identified in step 5.

8. If end of CBR file is not reached, repeat steps 5-7 for next record in CBR_file.

9. If end of CBR file is reached, repeat steps 5-7 for next CBR file.

10.If last CBR_file is completed, go to step 3 for next smaller node_number and repeat steps 4-9.

11. If steps 4-9 is complete for least node_number in a round, a loop execution is complete. Manual resetting for the loop execution on another movement folder may be undertaken.

A monitoring is kept about number of non-recalculated and recalculated lines. The figures are quite encouraging.

Progress is very observable in terms of time: if for step 2, a time (t1) is noted for completion of a folder, corresponding time for a folder identified in step 3 to complete is much less than t1. Progresses are very commendable as even for large node numbers, the tendency is followed.

Optimisation achieved in this process has led to development of quite complex programs. The level reached remains a trade-off between performances achieved and program complexity. The overall processing for this work took nearly 5 months over initially 3 laptops. Later, a fourth laptop was added. In the course of the weeks, ideas for further optimisations did crop up but program complexity as from flowcharts and algorithm analysis was really very big. On top of it, ensuring data integrity and program correctness over huge data files was risky.

The level of optimisation reached did give good enough functionality and performance. Being able to carry other work in parallel rendered program execution time acceptable.

\subsubsection{Evolution of Rates of Data Generation.}

Though rate of data generation is not most relevant, as it depends a lot on program design, data needed to be stored (including amounts of "useful" redundancies decided), its evolution, once a program design is reached and adhered to, remains a metric of program performance. As node numbers increase from 7 to 56 , average data generation rate dropped gradually from $300 \mathrm{~KB} / \mathrm{s}$ till $60 \mathrm{~KB} / \mathrm{s}$. This was measured by manually checking the file size by right-clicking on the file and view properties at intervals of 60 seconds and estimating the file growth occurring in that time and calculating the average file growth rate. The final output of data is deemed to be good.

\subsubsection{Overall Folder Sizes Noted.}

The overall folder sizes for each of the listed node numbers are as shown in table 2. Column headings are: $\mathrm{A} \rightarrow$ Node_number, $\mathrm{B} \rightarrow$ Average Folder size per movement folder/GB, $\mathrm{C} \rightarrow$ Total file size per node_number folder/GB.

\begin{tabular}{|c|c|c|c|c|c|}
\hline $\mathbf{A}$ & B & C & $\mathbf{A}$ & B & $\mathbf{C}$ \\
\hline 7 & 0.918 & 55.1 & 32 & 1.950 & 117 \\
\hline 8 & 0.955 & 57.3 & 33 & 2.000 & 120 \\
\hline 9 & 1.012 & 60.7 & 34 & 2.050 & 123 \\
\hline 10 & 0.953 & 57.2 & 35 & 2.100 & 126 \\
\hline 11 & 1.000 & 60.0 & 36 & 2.150 & 129 \\
\hline 12 & 1.022 & 61.3 & 37 & 2.183 & 131 \\
\hline 13 & 1.082 & 64.9 & 38 & 2.233 & 134 \\
\hline 14 & 1.130 & 67.8 & 39 & 2.283 & 137 \\
\hline 15 & 1.170 & 70.2 & 40 & 2.333 & 140 \\
\hline 16 & 1.178 & 70.7 & 41 & 2.383 & 143 \\
\hline 17 & 1.258 & 75.5 & 42 & 2.450 & 147 \\
\hline 18 & 1.305 & 78.3 & 43 & 2.483 & 149 \\
\hline 19 & 1.350 & 81.0 & 44 & 2.533 & 152 \\
\hline 20 & 1.373 & 82.4 & 45 & 2.567 & 154 \\
\hline 21 & 1.422 & 85.3 & 46 & 2.617 & 157 \\
\hline 22 & 1.468 & 88.1 & 47 & 2.667 & 160 \\
\hline 23 & 1.517 & 91.0 & 48 & 2.717 & 163 \\
\hline 24 & 1.563 & 93.8 & 49 & 2.783 & 167 \\
\hline 25 & 1.618 & 97.1 & 50 & 2.817 & 169 \\
\hline 26 & 1.667 & 100 & 51 & 2.867 & 172 \\
\hline 27 & 1.700 & 102 & 52 & 2.917 & 175 \\
\hline 28 & 1.750 & 105 & 53 & 2.967 & 178 \\
\hline 29 & 1.800 & 108 & 54 & 3.017 & 181 \\
\hline 30 & 1.850 & 111 & 55 & 3.067 & 184 \\
\hline 31 & 1.900 & 114 & 56 & 3.133 & 188 \\
\hline
\end{tabular}

Table 2: Overall Folder Sizes for MANET Route formulation

It can be observed that average folder sizes per movement and total folder size per node number are both increasing with increasing number of nodes. This is mainly due to longer records involving more nodes in MANET Route formulation.

\section{Conclusion.}

This piece of study follows up from previous work [66] and elaborates, with fine-granule details, the formulation of a methodology and implementation of a method of MANET Route Formulation and Tracking Nodes Energy Expenditure in Ubicomp MANETs based on exact positions of ubicomp nodes, which has been gathered using NS2. Strictly, for the work in this paper, simulator NS2 was not required; the processing was done in TCL programming language and using file manipulation. Processed data were stored using maximum decimal places allowable in TCL. Such a 
Proc. of The Seventh Intl. Conf. On Advances In Computing, Control And Networking - ACCN 2017

Copyright (C) Institute of Research Engineers and Doctors, USA .All rights reserved.

ISBN: 978-1-63248-134-4 doi: 10.15224/ 978-1-63248-134-4-15

methodology with modifications/refinements may be used by other researchers embarking on empirical research in ubicomp. This methodology has been the second of five components formulations over which empirical research [14-65] could be developed; this study however remains a complete one standing on its own.

This methodology has been devised and implemented irrespective of MANET nodes being supplied as infrastructure or not. The results of this study can serve towards better formulation of MANET Route Formulation and Tracking Nodes Energy Expenditure in ubicomp MANETs or to use this methodology with or without modifications, to prepare many off-the-shelf such components or to generate library files over various movement and communication patterns in ubicomp for NS2. This would successively facilitate work of further research by other researchers.

Further work identified remains developing the methodology for the last three components identified in section 1 of this paper.

\section{References}

[1] M. Kaleem GALAMALI, Assoc. Prof Nawaz MOHAMUDALLY, Towards Dependable Pervasive Systems-A Position and Vision Paper, CEET 2014

[2] M. Kaleem GALAMALI, Assoc. Prof Nawaz MOHAMUDALLY, Model of Energy Savings achievable with Location-aware Node-to-Node Transmission in UbiComp, CEET 2014

[3] M. Kaleem GALAMALI, Assoc. Prof Nawaz MOHAMUDALLY, Model of Energy Savings achievable with Location-aware Node-to-Node Transmission in UbiComp Using Location Refresh Intervals, CEET 2014

[4] M. Kaleem GALAMALI, Assoc. Prof Nawaz MOHAMUDALLY, Model of Energy Savings achievable with Location-aware Transmission in UbiComp Using Relays, CEET 2014

[5] M. Kaleem GALAMALI, Assoc. Prof Nawaz MOHAMUDALLY, Mathematical modeling of need of exact number of relays to ensure seamless mobility in mobile computing, CEET 2014

[6] M. Kaleem GALAMALI, Assoc. Prof Nawaz MOHAMUDALLY, Modelling of need for multiple relays for ensuring seamless mobility, CEET 2014

[7] M. Kaleem GALAMALI, Assoc. Prof Nawaz MOHAMUDALLY, Investigation of prominence of placements of relays in a ubicomp topography,

[8] M. Kaleem GALAMALI, Assoc. Prof Nawaz MOHAMUDALLY, Model of energy savings achievable with location-aware transmission in ubicomp using optimised number of relays.

[9] M. Kaleem GALAMALI, Assoc. Prof Nawaz MOHAMUDALLY, Investigation of Prominence of Placements of Optimised Number of Relays in a Ubicomp Topography using Location-Aware Transmission, CEET 2015.

[10] M. Kaleem GALAMALI, Assoc. Prof Nawaz MOHAMUDALLY, Extending Node Battery Availability in Ubicomp with Location-Aware Transmission, CEET 2015.

[11] M. Kaleem GALAMALI, Assoc. Prof Nawaz MOHAMUDALLY, Extending Node Battery Availability in Ubicomp with Location-Aware Transmission using Location Refresh Intervals, CEET 2015.
[12] M. Kaleem GALAMALI, Assoc. Prof Nawaz MOHAMUDALLY, Extending Node Battery Availability in Ubicomp with Location-Aware Transmission using Uniformly Placed Relays, CEET 2015.

[13] M. Kaleem GALAMALI, Assoc. Prof Nawaz MOHAMUDALLY, Extending Node Battery Availability in Ubicomp with Location-Aware Transmission Using Optimally Placed Relays, CEET 2015.

[14] M. Kaleem GALAMALI, Assoc. Prof Nawaz MOHAMUDALLY, Model of Sender Node Energy Savings Achievable with Location-Aware MANET Transmission in Ubicomp. ACCN 2016

[15] M. Kaleem GALAMALI, Assoc. Prof Nawaz MOHAMUDALLY, Model of Overall Node Energy Savings Achievable with Location-Aware MANET Transmission in Ubicomp. ACCN 2016

[16] M. Kaleem GALAMALI, Assoc. Prof Nawaz MOHAMUDALLY, Model of Sender Node Extra Energy Savings Achievable in MANET Against Direct Node-to-Node Transmission Using Location-Aware Transmission in Ubicomp. ACCN 2016

[17] M. Kaleem GALAMALI, Assoc. Prof Nawaz MOHAMUDALLY, Model of Overall Node Extra Energy Savings Achievable in MANET against Direct Node-to-Node Transmission Using Location-Aware Transmission in Ubicomp. ACCN 2016

[18] M. Kaleem GALAMALI, Assoc. Prof Nawaz MOHAMUDALLY, Model of Energy Consumption Ratio Achievable in MANET Using Location-Aware Transmission in Ubicomp. ACCN 2016

[19] M. Kaleem GALAMALI, Assoc. Prof Nawaz MOHAMUDALLY, Model of Minimum Energy Consumption Ratio Achievable in MANET Using LocationAware Transmission in Ubicomp. ACCN 2016

[20] M. Kaleem GALAMALI, Assoc. Prof Nawaz MOHAMUDALLY, Model of Maximum Energy Consumption Ratio Achievable in MANET Using LocationAware Transmission in Ubicomp. ACCN 2016

[21] M. Kaleem GALAMALI, Assoc. Prof Nawaz MOHAMUDALLY, Model of Overall Energy Consumption Fairness Ratio Achievable in MANET Using Location-Aware Transmission in Ubicomp. ACCN 2016

[22] M. Kaleem GALAMALI, Assoc. Prof Nawaz MOHAMUDALLY, Model of Overall Energy Consumption Fairness Proportion Achievable in MANET Using LocationAware Transmission for Ubicomp, CEET 2016

[23] M. Kaleem GALAMALI, Assoc. Prof Nawaz MOHAMUDALLY, Model of Minimum Fairness Proportion Achievable in MANET Using Location-Aware Transmission for Ubicomp, CEET 2016

[24] M. Kaleem GALAMALI, Assoc. Prof Nawaz MOHAMUDALLY, Model of Maximum Fairness Proportion Achievable in MANET Using Location-Aware Transmission for Ubicomp, CEET 2016

[25] M. Kaleem GALAMALI, Assoc. Prof Nawaz MOHAMUDALLY, Model of Sender Fairness Proportion Achievable in MANET Using Location-Aware Transmission for Ubicomp, CEET 2016

[26] M. Kaleem GALAMALI, Assoc. Prof Nawaz MOHAMUDALLY, Model of Distance Travelled by packets in MANETs using Location-Aware Transmission for Ubicomp, CEET 2016

[27] M. Kaleem GALAMALI, Assoc. Prof Nawaz MOHAMUDALLY, Model of Maximum CBR Distance Travelled by packets in MANETs using Location-Aware Transmission for Ubicomp, CEET 2016

[28] M. Kaleem GALAMALI, Assoc. Prof Nawaz MOHAMUDALLY, Model of Minimum CBR Distance Travelled by packets in MANETs using Location-Aware Transmission for Ubicomp, CEET 2016

[29] M. Kaleem GALAMALI, Assoc. Prof Nawaz MOHAMUDALLY, Model of Range CBR Distance Experienced by Transmissions in MANETs using LocationAware Transmission for Ubicomp, CEET 2016

[30] M. Kaleem GALAMALI, Assoc. Prof Nawaz MOHAMUDALLY, Trend Analyses of Parameters of Equations for Sender Node Energy Savings Achievable in ubicomp MANETs using Location-Aware Transmission, ACCN 2017. 
Proc. of The Seventh Intl. Conf. On Advances In Computing, Control And Networking - ACCN 2017

Copyright (C) Institute of Research Engineers and Doctors, USA .All rights reserved.

ISBN: 978-1-63248-134-4 doi: 10.15224/ 978-1-63248-134-4-15

[31] M. Kaleem GALAMALI, Assoc. Prof Nawaz MOHAMUDALLY, Trend Analyses of Parameters of Equations for Overall Node Energy Savings Achievable in ubicomp MANETs using Location-Aware Transmission, ACCN 2017.

[32] M. Kaleem GALAMALI, Assoc. Prof Nawaz MOHAMUDALLY, Trend Analyses of Parameters of Equations for Sender Node Extra Energy Savings Achievable in MANET against Direct Node-to-Node Location-Aware Transmission, ACCN 2017.

[33] M. Kaleem GALAMALI, Assoc. Prof Nawaz MOHAMUDALLY, Trend Analyses of Parameters of Equations for Overall Nodes Extra Energy Savings Achievable in MANET against Direct Node-to-Node Location-Aware Transmission, ACCN 2017.

[34] M. Kaleem GALAMALI, Assoc. Prof Nawaz MOHAMUDALLY, Trend Analyses of Parameters of Equations for Energy Consumption Ratio Achievable in Ubicomp MANET Using Location-Aware Transmission, ACCN 2017.

[35] M. Kaleem GALAMALI, Assoc. Prof Nawaz MOHAMUDALLY, Trend Analyses of Parameters of Equations for Minimum Energy Consumption Ratio Achievable in Ubicomp MANETs Using Location-Aware Transmission, ACCN 2017.

[36] M. Kaleem GALAMALI, Assoc. Prof Nawaz MOHAMUDALLY, Trend Analyses of Parameters of Equations for Maximum Energy Consumption Ratio Achievable in Ubicomp MANETs Using Location-Aware Transmission, ACCN 2017.

[37] M. Kaleem GALAMALI, Assoc. Prof Nawaz MOHAMUDALLY, Trend Analyses of Parameters of Equations for Overall Fairness Ratio Achievable in Ubicomp MANETs Using Location-Aware Transmission, ACCN 2017.

[38] M. Kaleem GALAMALI, Assoc. Prof Nawaz MOHAMUDALLY, Trend Analyses of Parameters of Equations for Energy Consumption Fairness Proportion Achievable in Ubicomp MANETs Using Location-Aware Transmission, CEET 2017

[39] M. Kaleem GALAMALI, Assoc. Prof Nawaz MOHAMUDALLY, Trend Analyses of Parameters of Equations for Minimum Fairness Proportion Achievable in Ubicomp MANETs Using Location-Aware Transmission, CEET 2017

[40] M. Kaleem GALAMALI, Assoc. Prof Nawaz MOHAMUDALLY, Trend Analyses of Parameters of Equations for Maximum Fairness Proportion Achievable in Ubicomp MANETs Using Location-Aware Transmission, CEET 2017

[41] M. Kaleem GALAMALI, Assoc. Prof Nawaz MOHAMUDALLY, Trend Analyses of Parameters of Equations for Sender Fairness Proportion Achievable in Ubicomp MANETs Using Location-Aware Transmission, CEET 2017

[42] M. Kaleem GALAMALI, Assoc. Prof Nawaz MOHAMUDALLY, Trend Analyses of Parameters of Equations for Packets Per Distance Achievable in Ubicomp MANETs Using Location-Aware Transmission, CEET 2017

[43] M. Kaleem GALAMALI, Assoc. Prof Nawaz MOHAMUDALLY, Trend Analyses of Parameters of Equations for Maximum CBR Distance Achievable in Ubicomp MANETs Using Location-Aware Transmission, CEET 2017

[44] M. Kaleem GALAMALI, Assoc. Prof Nawaz MOHAMUDALLY, Trend Analyses of Parameters of Equations for Minimum CBR Distance Achievable in Ubicomp MANETs Using Location-Aware Transmission, CEET 2017

[45] M. Kaleem GALAMALI, Assoc. Prof Nawaz MOHAMUDALLY, Trend Analyses of Parameters of Equations for Range CBR Distance Achievable in Ubicomp MANETs Using Location-Aware Transmission, CEET 2017

[46] M. Kaleem GALAMALI, Assoc. Prof Nawaz MOHAMUDALLY, Trend Analyses of Critical Values Obtained for Sender Node Energy Savings Achievable in Ubicomp MANETs Using Location-Aware Transmission, CEET 2017

[47] M. Kaleem GALAMALI, Assoc. Prof Nawaz MOHAMUDALLY, Trend Analyses of Critical Values Obtained for Overall Node Energy Savings Achievable in Ubicomp MANETs Using Location-Aware Transmission, CEET 2017
[48] M. Kaleem GALAMALI, Assoc. Prof Nawaz MOHAMUDALLY, Trend Analyses of Critical Values Obtained for Sender Node Extra Energy Savings Achievable in Ubicomp MANET Against Direct Node-to-Node LocationAware Transmission, CEET 2017

[49] M. Kaleem GALAMALI, Assoc. Prof Nawaz MOHAMUDALLY, Trend Analyses of Critical Values Obtained for Overall Nodes Extra Energy Savings Achievable in Ubicomp MANET Against Direct Node-to-Node LocationAware Transmission, CEET 2017

[50] M. Kaleem GALAMALI, Assoc. Prof Nawaz MOHAMUDALLY, Trend Analyses of Critical Values Obtained for Energy Consumption Ratio Achievable in Ubicomp MANETs Using Location-Aware Transmission Strategies, CEET 2017

[51] M. Kaleem GALAMALI, Assoc. Prof Nawaz MOHAMUDALLY, Trend Analyses of Critical Values Obtained for Minimum Energy Consumption Ratio Achievable in Ubicomp MANETs Using Location-Aware Transmission Strategies, CEET 2017

[52] M. Kaleem GALAMALI, Assoc. Prof Nawaz MOHAMUDALLY, Trend Analyses of Critical Values Obtained for Maximum Energy Consumption Ratio Achievable in Ubicomp MANETs Using Location-Aware Transmission Strategies, CEET 2017

[53] M. Kaleem GALAMALI, Assoc. Prof Nawaz MOHAMUDALLY, Trend Analyses of Critical Values Obtained for Overall Fairness Ratio Achievable in Ubicomp MANETs Using Location-Aware Transmission Strategies, CEET 2017

[54] M. Kaleem GALAMALI, Assoc. Prof Nawaz MOHAMUDALLY, Trend Analyses of Critical Values Obtained for Energy Consumption Fairness Proportion Achievable in Ubicomp MANETs Using Location-Aware Transmission Strategies, ACCN 2017.

[55] M Kaleem GALAMALI, Assoc. Prof Nawaz MOHAMUDALLY, Trend Analyses of Critical Values Obtained for Minimum Fairness Proportion Achievable in Ubicomp MANETs Using Location-Aware Transmission Strategies, ACCN 2017.

[56] M. Kaleem GALAMALI, Assoc. Prof Nawaz MOHAMUDALLY, Trend Analyses of Critical Values Obtaine for Maximum Fairness Proportion Achievable in Ubicomp MANETs Using Location-Aware Transmission Strategies, ACCN 2017.

[57] M. Kaleem GALAMALI, Assoc. Prof Nawaz MOHAMUDALLY, Trend Analyses of Critical Values Obtained for Sender Fairness Proportion Achievable in Ubicomp MANETs Using Location-Aware Transmission Strategies, ACCN 2017.

[58] M. Kaleem GALAMALI, Assoc. Prof Nawaz MOHAMUDALLY, Trend Analyses of Critical Values Obtained for Packets Per Distance Achievable in Ubicomp MANETs Using Location-Aware Transmission Strategies, ACCN 2017.

[59] M. Kaleem GALAMALI, Assoc. Prof Nawaz MOHAMUDALLY, Trend Analyses of Critical Values Obtained for Maximum CBR Distance Achievable in Ubicomp MANETs Using Location-Aware Transmission Strategies, ACCN 2017.

[60] M. Kaleem GALAMALI, Assoc. Prof Nawaz MOHAMUDALLY, Trend Analyses of Critical Values Obtained for Minimum CBR Distance Achievable in Ubicomp MANET Using Location-Aware Transmission Strategies, ACCN 2017.

[61] M. Kaleem GALAMALI, Assoc. Prof Nawaz MOHAMUDALLY, Trend Analyses of Critical Values Obtained for Range CBR Distance Achievable in Ubicomp MANETs Using Location-Aware Transmission Strategies, ACCN 2017.

[62] M. Kaleem GALAMALI, Assoc. Prof Nawaz MOHAMUDALLY, Extending Sender Node Battery Availability in Ubicomp with Location-Aware MANET Transmission, ACCN 2017.

[63] M. Kaleem GALAMALI, Assoc. Prof Nawaz MOHAMUDALLY, Extending Overall Node Battery Availability in Ubicomp with Location-Aware MANET Transmission, ACCN 2017

[64] M. Kaleem GALAMALI, Assoc Prof Nawaz MOHAMUDALLY, Extension of Sender Node Battery Extra Availability in Ubicomp with Location-Aware MANET Transmission Compared to Direct Node-To-Node Transmission, ACCN 2017

[65] M. Kaleem GALAMALI, Assoc. Prof Nawaz MOHAMUDALLY, Extension of Overall Node Battery Extra 
Proc. of The Seventh Intl. Conf. On Advances In Computing, Control And Networking - ACCN 2017

Copyright (C) Institute of Research Engineers and Doctors, USA .All rights reserved.

ISBN: 978-1-63248-134-4 doi: 10.15224/ 978-1-63248-134-4-15

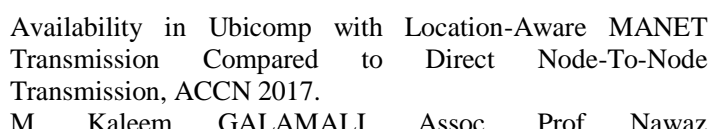

[66] M. Kaleem GALAMALI, Assoc. Prof Nawaz
MOHAMUDALLY, Methodology Formulation for Exact Location Tracking of Node Positions in Ubicomp MANETs Using NS2, ACCN 2017.

[67] Mohammed Humayun Kabir, Syful Islam, Md. Javed Hossain, Sazzad Hossain, Detail Comparison of Network Simulators, International Journal of Scientific \& Engineering Research, Volume 5, Issue 10, October-2014

[68] Arun Gupta, Web site blog "http://arungupta.co.in/blog/?p=37", title "segmentation fault in NS-2, 24 ${ }^{\text {th }}$ June 2012, accessed on $13^{\text {th }}$ March 2014

About Author (s):

Associate Professor Nawaz Mohamudally works at University of Technology, Mauritius (UTM) and has undertaken supervision of MPhil/PhD Students for many years.

M. Kaleem Galamali is a part-time student (achieved M Phil Transfer on 28.10.2014, currently PhD student) at UTM under supervision of A.P. Nawaz Mohamudally. 